J. Perinat. Med. 2 (1974) 276

\section{A comparative study of the epidemiological data of pre- gnancies with and without tendencies to premature delivery}

\author{
H. Weidinger, W. Wiest \\ Frauenklinik Mannheim \\ Fakultät für klinische Medizin Mannheim der Universität Heidelberg
}

Received January 21, 1974. Accepted June 15, 1974.
The prenatal causes that lead to premature delivery of a pregnancy are still unknown. In various studies several authors have tried to determine the etiological basis for premature birth $[1,2,3,7,8,11,13,14,15,18,20,29,31$, $32,35]$, but primarily because of the lack of statistical data, they have been unable to agree on concepts.

The aim of this study was to analyse statistically all factors that might be found in above average frequency in pregnancies with tendencies to premature delivery. The data obtained were then compared to a control group of patients whose pregnancies followed a normal course to term. We hoped the factors collected in this study would help us establish a catalogue of data, enabling us to treat patients who have tendencies toward premature delivery with appropriate preventive care, as Papiernik [25], SALING [27] and Thalmammer [30] have already proposed.

\section{Method}

The data collected had to be extensive enough so that we could recognize true differences in factors which when taken together pointed toward tendencies of premature delivery.

We studied two groups of patients. The first comprised 469 pregnancies with premature tendencies at the Universitäts-Frauenklinik, Klinikum Mannheim (from 1970-1973). Only those premature births that adhere to the WHO criteria of 1948 have been included in that group:

1. The birth weight of the child was 2500 gm or less.

\section{Curriculum vitae}

Hans Weidinger, $M . D$., Professor of Obstetrics and Gynecology and Pbysiology. 1929: Born in Nürnberg. 1955-1959: Surgical Department University Würzburg and Department of Internal Medicine. 1959 to 1967: I. Institut for Pbysiology University of Heidelberg (Prof. Dr. H. Schaefer). 1966: Habilitation "Das Vasomotorenzentrum in der Medulla oblongata; Versucbe zu seiner Lokalisation und

Funktion". 1967: Department of Obstetrics and Gjnecology Mannbeim University of Heidelberg (Prof. P. Stoll).

Main fields of interest: Electrophysiology, vegetative nervous system, circulation research of pregnant women and fetus, prematurity, physiology' of labor.

2. The length of pregnancy did not reach the end of the 37th week.

3. The fetus was living.

These three criteria were present in all cases considered. The second group (control group) of 472 pregnancies with normal birth weights served for comparison. These pregnancies were randomly selected during the same period according to the B-method. If, in that time period, a patient presented more than once, only one random pregnancy was evaluated and included in the study. 
For collecting data we prepared our own questionnaire. We included information known from the literature, and in addition further factors which, from our clinical experience, appeared to us important. The questionnaire comprised 160 areas of information.

Since the evaluation of the patients records was retrospective, factors such as living standard and habits could not be considered. A prospective study, in which these factors are being carefully evaluated, is in progress. Punch cards for data processing and coded for 160 information areas were computerized with the IBM 360/365. The statistical certainty for every single factor contained in the premature birth group and the control group was obtained with the Chi-SquareTest.

\section{Results}

The unlimited evaluations made possible by the 160 areas of information from the 941 questionnaires precluded consideration of every combination. For example, by simply comparing three factors - such as age, weight and height of the pregnant patient with the outcome of her pregnancy - the number of combinations proved so great it was practically impossible to evaluate. Thus summarization and grouping of the areas of information collected had to be undertaken. In order to clearly state our results, we describe only those that are clearly demonstrable and statistically certain.

\subsection{Constitutional factors}

\subsubsection{Age}

A comparison of age classes (those of very young and very old pregnant women) shows no disposition to premature delivery. The apparent increase of premature deliveries in women over 35 years of age shown in Tab. I is statistically not significant and is dependent on multiparity (see Tab. V).

* The questionnaire can be obtained by request from the authors.
Tab. I. Incidence of premature births correlated with maternal age.

\begin{tabular}{cccc}
\hline $\begin{array}{c}\text { age } \\
\text { (years) }\end{array}$ & control & premature & total \\
\hline$\leqq 19$ & 64 & 60 & 124 \\
$20-24$ & 131 & 129 & 260 \\
$25-29$ & 122 & 119 & 241 \\
$30-34$ & 101 & 91 & 192 \\
$35-39$ & 40 & 53 & 93 \\
$\geqq 40$ & 14 & 17 & 31 \\
total & 472 & 469 & 941 \\
critical value alpha & $=0.05$ & & 11.22 \\
chi-square & & & 2.80 \\
\hline
\end{tabular}

Tab. II. Incidence of premature birth correlated with maternal height.

\begin{tabular}{cccc}
\hline $\begin{array}{c}\text { height } \\
(\mathrm{cm})\end{array}$ & control & premature & total \\
\hline$\leqq 149$ & 8 & 11 & 19 \\
$150-154$ & 39 & 39 & 78 \\
$155-159$ & 78 & 95 & 173 \\
$160-164$ & 122 & 128 & 250 \\
$165-169$ & 143 & 112 & 255 \\
$\geqq 170$ & 68 & 51 & 119 \\
total & 458 & 436 & 894 \\
critical value alpha & 0.05 & & 11.22 \\
chi-square & & & 7.95 \\
\hline
\end{tabular}

Tab. III. Incidence of premature birth correlated with maternal weight.

\begin{tabular}{crcc}
\hline $\begin{array}{c}\text { weight } \\
(\mathrm{kg})\end{array}$ & control & premature & total \\
\hline 544 & 7 & 8 & 15 \\
$45-49$ & 34 & 48 & 82 \\
$50-54$ & 66 & 81 & 147 \\
$55-59$ & 68 & 51 & 119 \\
$60-64$ & 67 & 46 & 113 \\
$65-69$ & 35 & 35 & 70 \\
$70-74$ & 21 & 23 & 44 \\
$75-79$ & 14 & 8 & 22 \\
$80-84$ & 9 & 3 & 12 \\
$\geqq 85$ & 10 & 9 & 19 \\
total & 331 & 312 & 643 \\
critical value alpha $=0.05$ & & 16.59 \\
chi-square & & & 14.55 \\
\hline
\end{tabular}

\subsubsection{Height and weight}

When height and weight prior to conception are correlated in both groups (Tab. II and Tab. III) no significant difference in the frequency of 
premature deliveries could be found. Also the combinations of height and weight for calculating the true overweight and underweight classes, using the GeIGY Tables [17] of normal average weights as a standard, failed to point to any significant predisposition to premature delivery in either class.

\subsection{Social factors}

As seen in Tab. IV there is a significant tendency towards premature delivery in single, divorced and widowed mothers. Furthermore, in Tab. IV it may be noted that for the combination of age and marital status of the mother the tendency to premature delivery in every age group is markedly increased in single women.

Tab. IV. Incidence of premature births correlated with I marital status.

\begin{tabular}{lccc}
\hline \multicolumn{1}{c}{$\begin{array}{c}\text { marital } \\
\text { status }\end{array}$} & control & premature & total \\
\hline single & 42 & 85 & 127 \\
married & 419 & 367 & 786 \\
divorced or & & & \\
widowed & 11 & 17 & 288 \\
total & 472 & 469 & 941 \\
critical value alpha & 0.05 & 5.99 & \\
chi-square & & 19.28 & \\
\hline
\end{tabular}

Incidence of premature births correlated with marital status and maternal age.

\begin{tabular}{rrrrrrr}
\hline age & \multicolumn{3}{c}{ control } & \multicolumn{3}{c}{ premature } \\
& single married & $\begin{array}{c}\text { divor- single married } \\
\text { ced or } \\
\text { wid- } \\
\text { owed }\end{array}$ & $\begin{array}{c}\text { divor- } \\
\text { ced or } \\
\text { wid- } \\
\text { owed }\end{array}$ \\
\hline$\leqq 19$ & 14 & 50 & 0 & 28 & 32 & 0 \\
$20-24$ & 17 & 112 & 2 & 31 & 91 & 7 \\
$25-29$ & 6 & 111 & 5 & 16 & 100 & 3 \\
$30-34$ & 3 & 96 & 2 & 7 & 79 & 5 \\
$35-39$ & 0 & 38 & 2 & 3 & 49 & 1 \\
$\geqq 40$ & 2 & 12 & 0 & 0 & 16 & 1 \\
total & 42 & 419 & 11 & 85 & 367 & 17 \\
\hline
\end{tabular}

\subsection{Parity}

\subsubsection{Previous normal pregnancies}

Multiparity as a factor tending toward premature delivery appears to play a role only after the fourth pregnancy. Tab. $\mathrm{V}$ shows that after the third full term pregnancy the probability of premature delivery is greater. After the 4th and following pregnancies the tendency to premature delivery does not appear to change further with rising parity when correlated with the age groups. There is a significant increase in predisposition toward premature delivery from the age of 25 onwards after the third fullterm pregnancy. It is to be noted, however, that only the parity and not the age of the mother is the predisposing factor.

\subsubsection{Previous premature births, stillbirths and miscarriages}

In patients with a previous history of premature deliveries and also stillbirths the tendency for further premature deliveries is apparent. The tendency increases after two or more premature deliveries. The same holds true for miscarriages. As Tab. VI shows the tendency for patients with a history of previous premature deliveries to have repeat premature deliveries has a highly significant test value of 0.05 . Even using a critical test value of 0.0005 the significance of the latter is still apparent.

\subsection{Twin pregnancies, fetal-position, and placenta praevia}

Twin pregnancies and pathological fetal positions predisposed to premature delivery (Tab. VII). The occurrence of premature delivery in transverse lie and breech presentations is especially frequent. In every case of placenta praevia totalis a premature delivery occurred. Approximately $4 / 5$ of the patients with placenta praevia marginalis delivered prematurely.

\subsection{Endocrine factors}

With shortened (less than 23 days) and irregular menstrual cycles the incidence of premature deliveries is increased. In contrast patients with a history of lengthened menstrual cycles showed less tendency to deliver prematurely (Tab. VIII). No relationship appears to exist between menarche and tendency for premature delivery. 
Tab. V. Incidence of premature births after previous births. Incidence of premature births in multiparae correlated with maternal age.

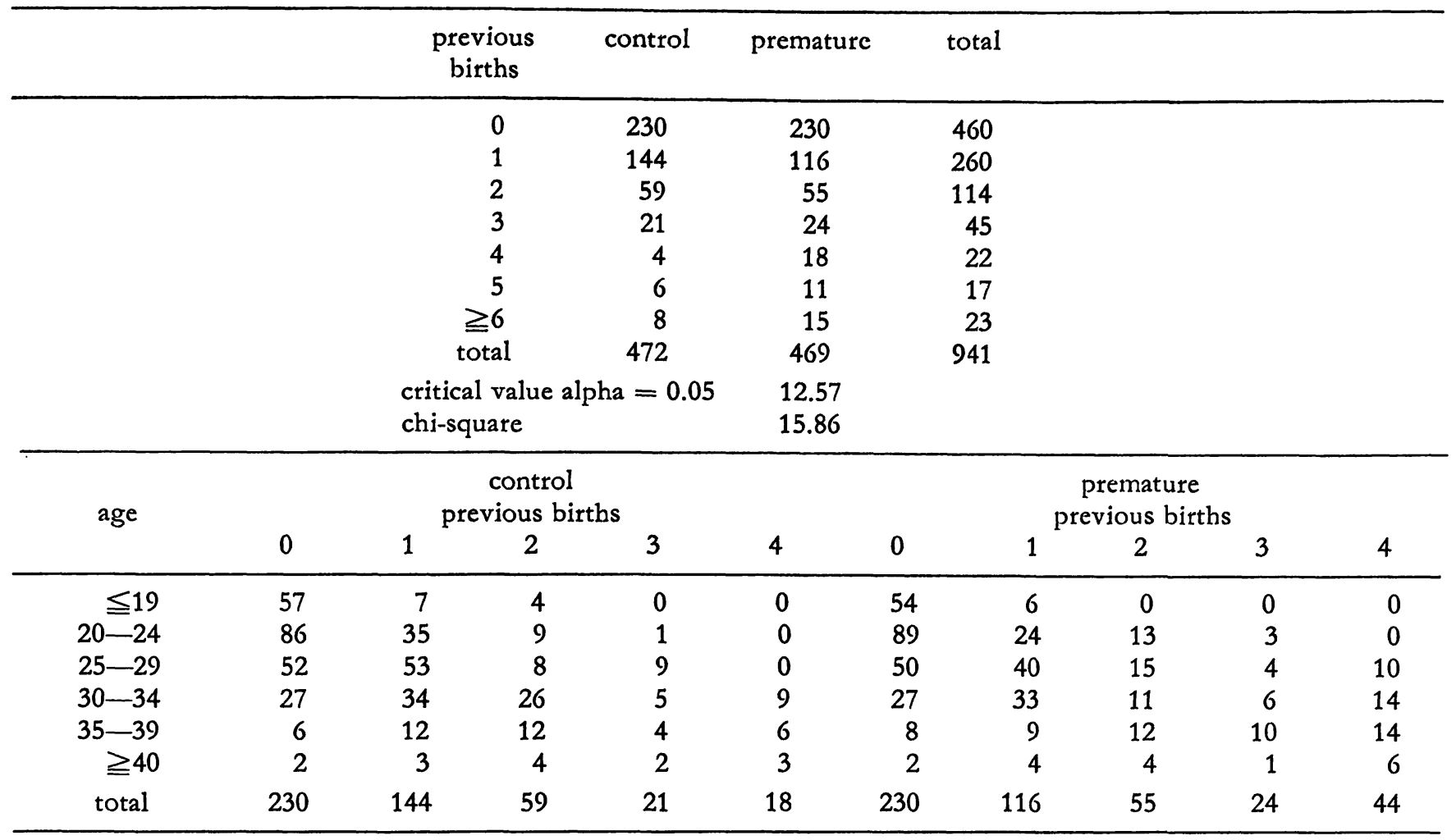

Tab. VI. Incidence of premature births after previous premature births, stillbirths and miscarriages.

\begin{tabular}{|c|c|c|c|}
\hline $\begin{array}{l}\text { previous } \\
\text { prematures }\end{array}$ & control & premature & total \\
\hline 0 & 450 & 370 & 820 \\
\hline 1 & 18 & 73 & 91 \\
\hline$\geqq 2$ & 4 & 25 & 29 \\
\hline total & 472 & 468 & 940 \\
\hline \multicolumn{2}{|c|}{$\begin{array}{l}\text { critical value alpha }=0.05 \\
\text { chi-square }\end{array}$} & $\begin{array}{r}5.99 \\
14.24\end{array}$ & \\
\hline stillbirths & control & premature & total \\
\hline 0 & 462 & 423 & 885 \\
\hline$\geqq 1$ & 10 & 46 & 56 \\
\hline total & 472 & 469 & 941 \\
\hline \multicolumn{2}{|c|}{$\begin{array}{l}\text { critical value alpha }=0.05 \\
\text { chi-square }\end{array}$} & $\begin{array}{r}3.84 \\
24.86\end{array}$ & \\
\hline
\end{tabular}

\begin{tabular}{cccc}
\hline miscarriages & control & premature & total \\
\hline 0 & 374 & 320 & 694 \\
1 & 73 & 95 & 168 \\
$2+3$ & 23 & 37 & 60 \\
$\geqq 4$ & 2 & 15 & 17 \\
total & 472 & 467 & 939 \\
critical value alpha & $=0.05$ & 7.82 & \\
chi-square & & 20.26 & \\
\hline
\end{tabular}

Tab. VII. Incidence of premature birth in pregnant women in twin pregnancies with varying fetal positions and different placental locations.

\begin{tabular}{|c|c|c|c|}
\hline twins & control & premature & total \\
\hline no & 458 & 423 & 881 \\
\hline yes & 14 & 46 & 60 \\
\hline total & 472 & 469 & 941 \\
\hline \multirow{2}{*}{\multicolumn{2}{|c|}{$\begin{array}{l}\text { critical value alpha }=0.05 \\
\text { chi-square }\end{array}$}} & \multirow{2}{*}{\multicolumn{2}{|c|}{$\begin{array}{r}3.84 \\
18.45\end{array}$}} \\
\hline & & & \\
\hline fetal position & control & premature & total \\
\hline vertex & 450 & 358 & 808 \\
\hline transverse lie & 3 & 15 & 18 \\
\hline breech & 19 & 96 & 115 \\
\hline total & 472 & 469 & 941 \\
\hline \multirow{2}{*}{\multicolumn{2}{|c|}{$\begin{array}{l}\text { critical value alpha }=0.05 \\
\text { chi-square }\end{array}$}} & \multirow{2}{*}{\multicolumn{2}{|c|}{$\begin{array}{r}5.99 \\
70.02\end{array}$}} \\
\hline & & & \\
\hline \multicolumn{4}{|l|}{ location } \\
\hline \multirow{3}{*}{$\begin{array}{l}\text { normal } \\
\text { placenta praevia } \\
\text { totalis } \\
\text { placenta praevia } \\
\text { marginalis }\end{array}$} & 469 & 445 & 914 \\
\hline & 0 & 11 & 11 \\
\hline & 3 & 13 & 16 \\
\hline \multirow{3}{*}{$\begin{array}{l}\text { total } \\
\text { critical value alph } \\
\text { chi-square }\end{array}$} & 472 & 469 & 941 \\
\hline & $=0.05$ & 5.99 & \\
\hline & & 17.87 & \\
\hline
\end{tabular}


Tab. VIII. Incidence of premature births in pregnant women with normal and varying menstrual histories.

\begin{tabular}{lrcr}
\hline \multicolumn{1}{c}{ cycle } & control & premature & total \\
\hline regular & 347 & 323 & 670 \\
shortened & 9 & 18 & 27 \\
prolonged & 27 & 10 & 37 \\
irregular & 51 & 66 & 117 \\
total & 434 & 417 & 851 \\
critical value alpha & 0.05 & 7.82 & \\
chi-square & & 13.26 & \\
\hline
\end{tabular}

\subsection{Illnesses and complications previous to the pregnancy}

\subsubsection{Pyelonephritis}

It is especially apparent that there is a marked predisposition to premature delivery when the patient contracted pyelonephritis prior to a pregnancy. Tab. IX shows the significant increase in premature births associated with pyelonephritis developing before pregnancy. A statistical comparison of pyelonephritis in the various age-groups shows no difference between young or older pregnant women.

Tab. IX. Incidence of premature birth correlated with a history of pyelonephritis before pregnancy.

\begin{tabular}{lrcr}
\hline $\begin{array}{c}\text { pyelonephritis } \\
\text { before pregnnancy }\end{array}$ & control & premature & total \\
\hline no & 461 & 408 & 869 \\
yes & 11 & 57 & 68 \\
total & 472 & 465 & 937 \\
critical value alpha & $=0.05$ & 3.84 & \\
chi-square & & 34.30 & \\
\hline
\end{tabular}

Tab. X. Incidence of premature birth after curettage.

\begin{tabular}{crcr}
\hline curettage & control & premature & total \\
\hline 0 & 462 & 410 & 872 \\
1 & 9 & 44 & 53 \\
$\geqq 2$ & 1 & 14 & 15 \\
total & 472 & 468 & 940 \\
critical value alpha & 0.05 & 5.99 & \\
chi-square & & 37.46 & \\
\hline
\end{tabular}

\subsubsection{Curettage}

In women who previously have had a curettage delivery is significantly more frequently premature (Tab. X). The predisposition for pre- mature delivery increases with the number of curettages.

\subsection{Illnesses and complications during the pregnancy}

\subsubsection{Hyperemesis gravidarum and EPH- complex}

Whereas hyperemesis gravidarum predisposes to early delivery (Tab. XI) patients with the EPHcomplex (late toxemia of pregnancy) no longer significantly showed such a predisposition when all forms of late toxemias were considered. In

Tab. XI. Incidence of premature birth following a history of hyperemesis gravidarum.

\begin{tabular}{lccr}
\hline $\begin{array}{l}\text { hyperemesis } \\
\text { gravidarum }\end{array}$ & control & premature & total \\
\hline no & 459 & 428 & 887 \\
yes & 13 & 37 & 50 \\
total & 472 & 465 & 937 \\
critical value alpha & 0.05 & 3.84 & \\
chi-square & & 12.55 & \\
\hline
\end{tabular}

Tab. XII. Incidence of premature birth in pregnant women with hypertension.

\begin{tabular}{cccc}
\hline $\begin{array}{c}\text { diastolic } \\
\text { blood pressure }\end{array}$ & control & premature & total \\
$\leqq 69$ & 20 & 41 & 61 \\
$70-79$ & 73 & 90 & 163 \\
$80-89$ & 202 & 172 & 374 \\
$90-99$ & 130 & 98 & 228 \\
$100-109$ & 24 & 33 & 57 \\
$100-119$ & 15 & 9 & 24 \\
$\geqq 120$ & 7 & 23 & 30 \\
total & 471 & 466 & 937 \\
critical value alpha & 0.05 & 12.57 & \\
chi-square & & 27.33 & \\
\hline systolic & control & premature & total \\
blood pressure & $\cdot$ & & \\
\hline$\leqq 99$ & 3 & 10 & 13 \\
$100-119$ & 89 & 87 & 176 \\
$120-139$ & 268 & 239 & 507 \\
$140-159$ & 93 & 91 & 184 \\
$\geqq 160$ & 18 & 38 & 56 \\
total & 471 & 465 & 936 \\
critical value alpha $=0.05$ & 9.87 & \\
chi-square & & 7.72 & \\
\hline
\end{tabular}


Tab. XIII. Incidence of premature birth in pregnant women with edema and proteinuria.

\begin{tabular}{lccc}
\hline \multicolumn{1}{c}{ edema } & control & premature & total \\
\hline no & 347 & 369 & 716 \\
mild & 101 & 33 & 134 \\
moderate & 18 & 40 & 58 \\
severe & 6 & 27 & 33 \\
total & 472 & 469 & 941 \\
critical avlue alpha & 0.05 & 7.82 & \\
chi-square & & 56.88 & \\
\hline \multicolumn{1}{c}{ proteinuria } & control & premature & total \\
\hline no & 350 & 218 & 568 \\
mild & 105 & 148 & 253 \\
moderate & 13 & 59 & 72 \\
severe & 4 & 43 & 47 \\
total & 472 & 468 & 940 \\
critical value alpha & 0.05 & 7.82 & \\
chi-square & & 99.72 & \\
\hline
\end{tabular}

patients with markedly increased blood pressure (the highest mean value over three consecutive days), with a diastolic pressure over $120 \mathrm{mmHg}$ and a systolic pressure over $160 \mathrm{mmHg}$ and in those with low blood pressure (a diastolic pressure below $80 \mathrm{mmHg}$ and also systolic pressure below $100 \mathrm{mmHg}$ ), a significant increase in the incidence of premature deliveries was noted (Tab. XII). In patients with severe and moderate edema a marked increase in the frequency of premature deliveries became evident. However, when one considers the three designations of edema, namely mild, moderate and severe together no difference in the rate of premature births is noted in comparison to the control group. The opposite is true with proteinuria, where even traces of protein in the urine proved to increase the rate of premature birth significantly (Tab. XIII).

\subsubsection{Urinary tract infections and febrile illnesses}

There is a significant increase in the rate of premature deliveries in patients with a history of urinary tract infections and febrile illnesses of unknown origin (e. g. viral infections) during their pregnancy (Tab. XIV).

\subsubsection{Bleeding during pregnancy}

Tab. XV shows a significant increase in the incidence of premature births in patients with a history of bleeding before the 28th week of gestation. Over $1 / 3$ of the total number of premature births followed pregnancies in which there was a history of bleeding.

Tab. XIV. Incidence of premature birth after infection of the urinary tract and after febrile illnesses during pregnancy.

\begin{tabular}{|c|c|c|c|}
\hline $\begin{array}{l}\text { urinary tract } \\
\text { infection }\end{array}$ & control & premature & total \\
\hline no & 451 & 367 & 818 \\
\hline yes & 21 & 98 & 119 \\
\hline total & 472 & 465 & 937 \\
\hline \multicolumn{2}{|c|}{$\begin{array}{l}\text { critical value alpha }=0.05 \\
\text { chi-square }\end{array}$} & \multicolumn{2}{|l|}{$\begin{array}{r}3.84 \\
58.40\end{array}$} \\
\hline $\begin{array}{l}\text { febrile } \\
\text { illnesses }\end{array}$ & control & premature & total \\
\hline no & 446 & 335 & 781 \\
\hline yes & 25 & 130 & 155 \\
\hline total & 471 & 465 & 936 \\
\hline \multicolumn{2}{|c|}{$\begin{array}{l}\text { critical value alpha }=0.05 \\
\text { chi-square }\end{array}$} & $\begin{array}{r}3.84 \\
86.87\end{array}$ & \\
\hline
\end{tabular}

Tab. XV. Incidence of premature birth after bleeding prior to the 28 th week and after the 28 th week of pregnancy.

\begin{tabular}{lccc}
\hline $\begin{array}{l}\text { bleeding in } \\
\text { the first 28 } \\
\text { weeks of } \\
\text { pregnancy }\end{array}$ & control & premature & total \\
\hline no & 459 & 290 & 749 \\
yes & 13 & 175 & 188 \\
total & 472 & 465 & 937 \\
$\begin{array}{l}\text { critical value alpha } \\
\text { chi-square }\end{array}$ & 0.05 & 4.38 & \\
\hline & & 177.69 & \\
bleeding after & control & premature & total \\
the 28th week of & & & \\
pregnancy & & & \\
\hline no & 458 & 286 & 744 \\
yes & 14 & 179 & 193 \\
total & 472 & 465 & 937 \\
critical value alpha & 0.05 & 3.84 & \\
chi-square & & 180.78 & \\
\hline
\end{tabular}


Tab. XVI. Incidence of premature birth in pregnant women with anemia.

\begin{tabular}{cccc}
\hline $\begin{array}{c}\text { Hb before } \\
\text { delivery }\end{array}$ & control & premature & total \\
\hline$\leqq 8,9$ & 2 & 27 & 29 \\
$9,0-9.9$ & 3 & 49 & 52 \\
$10.0-10.9$ & 15 & 75 & 90 \\
$11.0-11.4$ & 28 & 58 & 86 \\
$11.5-11.9$ & 24 & 37 & 61 \\
$12.0-12.9$ & 113 & 90 & 203 \\
$\geqq 13.0$ & 157 & 103 & 260 \\
total & 342 & 439 & 781 \\
critical value alpha $=$ & 0.05 & 12.57 & \\
chi-square & & 119.09 & \\
\hline
\end{tabular}

\subsubsection{Anemia}

A tendency to premature delivery was noted in patients with anemia with $\mathrm{Hb}$ values under $12 \mathrm{mg} \%$. Tab. XVI shows an increased significance for a decreasing $\mathrm{Hb}$ value. Interestingly enough no correlation between the values for $\mathrm{Hb}$ and bleeding during pregnancy could be revealed; apparently bleeding during pregnancy does not lead to decreased values for $\mathrm{Hb}$.

\section{Discussion}

Our results in part agree and in part disagree with data reported in the literature. In agreement with Abramowicz and Kass [1, 2, 3], Baird [5], Effkemann [14], Hoyer and Thalmammer [20] our results indicate that single mothers show a great tendency for premature deliveries. Furthermore with respect to those patients who have had previous premature deliveries, stillborns and miscarriages our results correspond to those of BAIRD [5] and Terris and Gold [32]. We cannot say, for certain, whether an isthmocervical insufficiency is present or occurs in patients with a history of miscarriages and/or premature deliveries. The findings, obtained for premature birth-tendencies in patients with a history of curettage would nevertheless tend to support that idea.

BAIRD [5] denies a tendency for premature births in twin pregnancies since the latter at term can have a birth-weight under $2500 \mathrm{mg}$. In contrast we can only agree with Wolfram [36] and DöRING $[9,10]$ that twin pregnancies fre- quently are premature, because in our study we have included only those premature births that presented before the 38th week of gestation for delivery and that showed a marked tendency for prematurity. Also with regard to the fetal position, our results are in agreement with those cited in the literature $[23,36]$. We found exactly as these authors did that pathological fetal positions tend to premature delivery. Whereas BRAun et al. [7] and we also found a high rate of prematurity with placenta praevia. Anderson et al. [4] denies that placenta praevia is a cause for premature births.

In agreement with others $[4,5,7,8,19,33,34]$ we found that bleeding during pregnancy and also anemia [2, 22, 24] predisposed to prematurity. Although Abramowicz [1] states that the rate of premature births becomes greater the more severe the anemia is, we could convincingly show that hemoglobin values of under $12 \mathrm{mg} \%$ predisposed to premature birth.

Hyperemesis gravidarum also predisposes to premature births as Hoyer and Thal hammer [20] have reported. WILKERson et al. [34] found in agreement with our study an increased rate of premature deliveries in patients with pyelonephritis and urinary tract infections. BAIRD [5] and BRown et al. [8] have rejected that association, although SALA et al. [26] showed in animal experiments that uterine contractions and premature births resulted from urinary tract infections.

It must be mentioned here however that we also observed that the rate of premature deliveries predominated in patients of lower social status. Nevertheless these findings correspond to the same group of pregnant women who failed to make use of prenatal care [5]. In addition most of these patients were single mothers in whom the rate of premature delivery is very high anyway. The same holds true for pregnant women, who are heavy smokers $[16,28]$.

From our studies we are not in agreement with the literature $[1,2,3,4,5,12,20]$ that age, height and weight prior to conception have no influence upon the frequency of premature births. Most of the earlier investigators reported that very young and very old pregnant women tend to deliver prematurely. HoYer and ThaLHAMMER [20] found a higher frequency of pre- 
mature deliveries in mothers under 21 years of age and also in mothers between the age of 31 and 35 years. HrgDoN [18] contends that pregnant women over the age of 40 do not tend to give birth prematurely. These conflicting results certainly arise through the fact that first, many young pregnant women are single (see above); second, the authors named above have defined premature birth only for a weight of under $2501 \mathrm{mg}$ whereas we did not include in our study all babies with births-weights under $2501 \mathrm{mg}$ which were born after the 37th week of gestation. Terris and Gold [32] indicated that $46 \%$ of premature babies defined only by birth weight had a period of gestation of over 37 weeks. DrILLIEN [13] found that in young nulliparas $50 \%$ and in multiparas $33 \%$ of the premature babies with birth weights under $2501 \mathrm{mg}$ and a period of gestation of 38 weeks and longer were born. In accordance with TERris and Gold [31] we could not confirm the results of BAIRD [5] who indicated a tendency to premature delivery in the very small pregnant woman.

Although Donnelley et al. [12] states that nulliparae more frequently have premature deliveries than do multiparae, we as SAling [27] could not verify these results. In addition, in contrast to what DoNnelly et al. [12] have said, we found that there is a higher frequency of premature births already after the fourth and not only after the sixth pregnancy. TERRIS and GoLD [32] reported no significant differences in age and menarche or in frequency and regularity of menstrual periods. KIRCHHOFF [21] reported that a late menarche predisposes to premature births. With respect to the menarche our findings resemble those of TERris and Gold [32]. However, in contrast to what he stated, we found that women with shortened or irregular menstrual periods have significantly more premature deliveries than other women.

Many authors contend that the EPH-complex (late toxemias of pregnancy) is the dominating factor in premature delivery $[1,2,3,4,5,12,23]$. In our study we could not confirm that contention. Hoyer and Thalmammer [20] also indicate that the predisposition to premature delivery in pregnant women with late toxemias or the EPH-complex is of little significance. Brown et al. [8] maintain that women with late toxemia or the EPH-complex have no higher frequency of premature deliveries that do women with the EPH-complex and concomitant bleeding. These differences in opinions arise because not all authors have obtained their results through comparative studies and because they have failed to differentiate between the monosymptomatic and the polysymptomatic EPH-complexes and their severity. Furthermore, it must be mentioned that babies from mothers with the EPH-complex may be underweight and retarded owing to placental insufficiency. ABRAMOwICZ et al. [1] write "that toxemia or preeclampsia is perhaps the most common obstetric complication that is significantly correlated with low birthweight". If only the birth weight is used to define prematurity and the period of gestation is disregarded then the rate of premature births will be higher. Our results showed that it is necessary that the three cardinal symptoms of late toxemia or the EPH-complex (namely edema, proteinuria and hypertension) be critically applied as yardsticks. Only then is it possible to show without a doubt that a definite hypertension with systolic values over $160 \mathrm{mmHg}$ or below $100 \mathrm{mmHg}$ and diastolic values over $120 \mathrm{mmHg}$ or below $80 \mathrm{mmHg}$ predisposes to premature delivery. On the other hand, the presence of proteinuria - even traces of albumen in the urine - signals the possibility of a premature delivery.

\subsection{Proposal for the prevention list}

In composing a questionnaire that would yield information about the risks or predisposing factors leading to premature delivery the following statement can be made based on our results. To the list that Papiernik [25], Saling [27] and Thalmammer [30] prepared for recognizing predisposition to premature deliveries we added the following additional or newly acceptable risk factors with high point values:

1. $\mathrm{Hb}$ value in $\mathrm{mg} \%$,

2. Previous curettages,

3. Multiparity from the fourth pregnancy on, 
4. Late toxemias or the EPH-Complex should be divided into

a) proteinuria

b) hypertension

c) edema

and each of these three categories should be further subdivided into three degrees of severity.
Finally it appears important that in future statistical studies of the frequency of premature deliveries one should not use only birth weight as a criterion of prematury but also the duration of gestation.

\section{Summary}

The causes of premature births remain unknown. In the present studies we have tried to detect factors occurring in above average frequency in pregnant women who tended to have premature deliveries. We compared these factors with those of a control group of gravid women who showed no tendencies for premature deliveries.

To evaluate these factors we composed a questionnaire which consisted of 160 areas of information for each pregnant patient. The two groups of gravid women were evaluated with a computer program. The first groups consisted of 469 pregnancies ending in premature deliveries during the years 1970-1973. Only those patients were evaluated in whom firstly the newborn had a birth weight of $2500 \mathrm{gm}$ or less; secondly the period of gestation did not exceed 37 weeks, and thirdly the fetus was born alive. The control group consisted of 472 patients hospitalized during the same time who delivered babies with normal birth weights; these patients served for comparison. The BSelection-method was used to select these patients. The I. B. M. 360/365 data processing and punch card analysis was carried out at the German Cancer Research Center in Heidelberg. The Chi-square-method was applied to statistically evaluate the factors.

Our computer analysis revealed that the following factors especially predisposed to premature delivery, with a probability of error less than 0.0005 :

1. Single marital status of the mother

2. Previous prematurity, stillborns and miscarriages

3. Twins

4. Pathological fetal positions

5. Placenta praevia

6. Previous curettages

7. Pyelonephritis before pregnancy

8. Urinary tract infection during pregnancy

9. Febrile illnesses during pregnancy

10. Hyperemesis gravidarum

11. Systolic bloodpressures over $160 \mathrm{mmHg}$ and below $100 \mathrm{mmHg}$

12. Diastolic bloodpressures over $120 \mathrm{mmHg}$ and below $80 \mathrm{mmHg}$

13. Proteinuria (even traces)

14. Marked edema

15. Bleeding during pregnancy

16. Anemia of $12 \mathrm{mg} \% \mathrm{Hb}$ or less before delivery

A probability of error of less than 0.005 was noted for:

17. Shortened and irregular menstrual cycles

A probability of error of less than 0.025 was shown for:

18. Two or more fullterm pregnancies.

We could find no predisposition to premature delivery for differences in age-groups, height and weight prior to conception of the patients. In addition, when summarising the three components of the EPH-complex into one factor no significant tendency for premature delivery could be seen with any certainty. Here our results differ from those of other authors, who found that young or very old, or very small patients tended to give birth prematurely $[1,2,3,4,5,12,20]$. These authors however composed their premature birth groups according to birth weight only.

The statements of ANDERson et al. [4], Baird [5] and DonNELIY et al. [12] indicating that late toxemias or the EPH-complex predispose to prematurity also differ from our results, primarily because these authors failed to evaluate a control group.

In our study we found six factors which should be added to the list of criteria proposed by Papiernik [25] Saling [27] and Thalmammer [30] for detecting the risks of premature deliveries.

1. $\mathrm{Hb}$ value in $\mathrm{gm} \%$

2. Previous curettages

3. Multiparity from the fourth pregnancy on

4. Edema

5. Hypertension

6. Proteinuria.

Factors 4, 5 and 6 must at the same time be subdivided into three degrees of severity. It is important in future statistical studies on the tendency to premature delivery that the term - premature birth - should be clearly defined. As criteria we suggest that at least a birth weight of $500 \mathrm{~g}$ to $2500 \mathrm{~g}$ and a gestational period up to and including the 37 th week should be considered.

Keywords: Constitution, epidemiology, prematurity, questionnaire. 


\section{Zusammenfassung}

Epidemiologische Daten bei Schwangerschaften mit und ohne Frühgeburtsbestrebungen

Die Ursachen für das Auftreten von Frühgeburten sind noch weitgehend unbekannt. Es wurde deshalb von uns versucht, Faktoren zu finden, die bei Schwangeren mit Frühgeburtsbestrebung überdurchschnittlich häufig gegenüber einem Kontrollkollektiv von Schwangeren ohne Frühgeburtsbestrebungen auftreten.

Zur Erarbeitung dieser Faktoren wurde ein Fragebogen erstellt, der 160 Informationseinheiten enthielt und für jede Schwangere retrospektiv ausgefüllt wurde. Zwei Kollektive von Schwangeren kamen zur Auswertung. Das eine Kollektiv bestand aus 469 Schwangeren mit Frühgeburten in den Jahren 1970 bis 1973 an der Städt. Frauenklinik Mannheim. Die Schwangeren wurden nur dann in die Auswertung einbezogen, 1. wenn das Neugeborene ein Gewicht von $2500 \mathrm{~g}$ oder darunter aufwies, 2. wenn die Tragzeit die 37. Woche nicht überschritt und 3. wenn der Fet bei Klinikaufnahme lebte. Zum Vergleich diente ein Kontrollkollektiv, das aus 472 Schwangeren mit normalgewichtigen Neugeborenen des gleichen Zeitraums bestand. Die Schwangeren wurden nach der B-Stichprobe ermittelt. Die Verarbeitung der Daten erfolgte mit einer elektronischen Rechenanlage I. B. M. 360/365 (Krebsforschungszentrum Heidelberg) mit Lochkarten. Die statistische Auswertung der Faktoren wurde nach dem Chi-quadrat-Test vorgenommen.

Bei der Auswertung zeigte sich, daß insbesondere folgende Faktoren zur Frühgeburt disponieren:

Mit einer Irrtumswahrscheinlichkeit von kleiner als 0,0005:

1. Lediger Familienstand der Mutter,

2. Vorausgegangene Früh-, Tot- und Fehlgeburten,

3. Gemini,

4. Pathologische Kindslagen,

5. Placenta praevia,

6. Vorausgegangene Curettagen,

7. Pyelonephritis vor der Gravidität,

8. Infekte der ableitenden Harnwege während der Gravidität,

9. Fieberhafte Erkrankungen während der Gravidität,

10. Hyperemesis gravidarum,

11. Systolischer Blutdruck über $160 \mathrm{mmHg}$ und unter $100 \mathrm{mmHg}$,

12. Diastolischer Blutdruck über $120 \mathrm{mmHg}$ und unter $80 \mathrm{mmHg}$,
13. Proteinurie (schon Spuren),

14. Ausgeprägte Odeme,

15. Blutungen in der Schwangerschaft,

16. Anämie unter $12 \mathrm{~g} \% \mathrm{Hb}$ vor der Geburt.

Mit ciner Irrtumswahrscheinlichkeit von kleiner als 0,005:

17. Verkürzter und unregelmäßiger Zyklus.

Mit einer Irttumswahrscheinlichkeit von kleiner als 0,025:

18. Zwei ausgetragene Schwangerschaften und mehr.

Wir konnten keine Disposition zur Frühgeburt bei den unterschiedlichen Altersgruppen, der Größe und dem präkonzeptionellen Gewicht der Schwangeren finden. Außerdem hat sich gezeigt, daß bei Zusammenfassung der Spätgestose (EPH-Komplex) als einen Faktor, keine signifikante Frühgeburtsbestrebung zu sichern ist. Die unterschiedlichen Ergebnisse $\mathrm{zu}$ anderen Autoren, die fanden, daß junge und auch sehr alte, sowie sehr kleine Schwangere zur Frühgeburt neigen $[1,2,3,4,5,12,20]$ sehen wir darin, daß diese Autoren ihr Frühgeburtenkollektiv nur nach dem Geburtsgewicht definierten. Die Angaben von Anderson et al. [4], BaIrd [5] und DonNELLY et al. [12], daß die Spätgestose zur Frühgeburt disponiert, weicht deshalb von unseren Ergebnissen $a b$, weil diese Autoren kein Vergleichskollektiv ausgewertet haben.

Bei unseren Untersuchungen wurden 6 Faktoren ermittelt, die neu in die von Papiernik [25], Saling [27] und ThalHAMMER [30] aufgestellten Kataloge zur Erkennung des Frühgeburtenrisikos aufgenommen werden müßten.

1. Hämoglobingehalt in $\mathrm{g} \%$,

2. Vorausgegangene Curettagen,

3. Multiparität ab der 4. Schwangerschaft,

4. Odeme,

5. Hypertonie,

6. Proteinurie.

Dabei müssen die bei 4., 5. und 6. genannten Faktoren jeweils mindestens in 3 Schweregrade unterteilt werden.

Bei künftigen Statistiken über die Frühgeburtsbestrebung ist es wichtig, eine einheitliche Definition der Frühgeburt zu verwenden. Wir schlagen als Kriterium vor, daß mindestens das Geburtsgewicht (von 500 bis $2500 \mathrm{~g}$ ) und die Tragzeit (bis einschließlich der 37. Woche) gleichzeitig berücksichtigt werden müssen.

Schlüsselwörter: Epidemiologie, Fragebogen, Frühgeburt, Konstitution.

$$
\text { if }
$$

\section{Résumé}

Données épidémiologiques dans les groșsesses avec et sans tendance à accouchement prématuré

Les causes des accouchements prématurés sont encore en grande partie inconnues, et c'est ce qui nous a amené à tâcher de découvrir les facteurs qui apparaissent plus fréquemment chez les femmes enceintes montrant une tendance à accoucher avant terme que chez d'autres dépourvues de cette tendance et classées dans un groupe de contrôle.

On a établi à cet effet un questionnaire contenant 160 unités d'information et rempli rétrospectivement pour chaque femme enceinte répartie dans l'un des deux groupes 


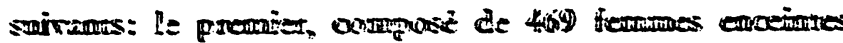

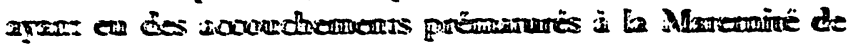

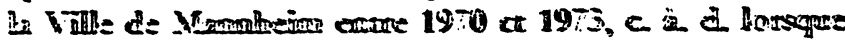

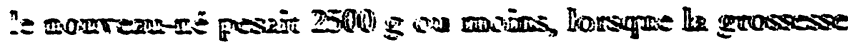

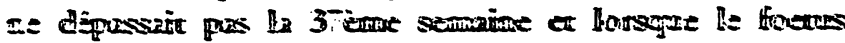

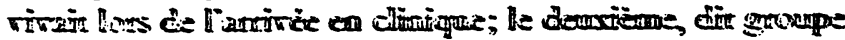

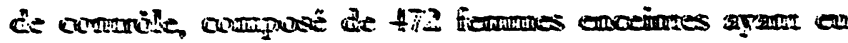

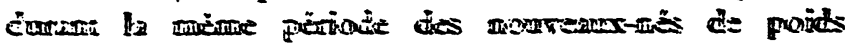

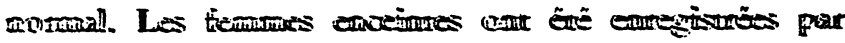

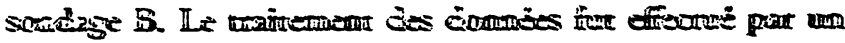

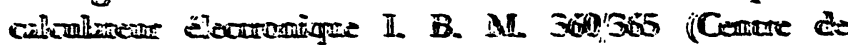

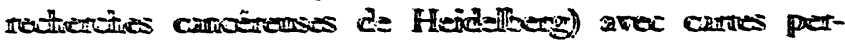
ivarios

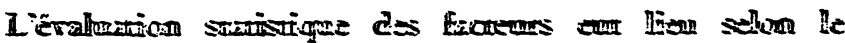

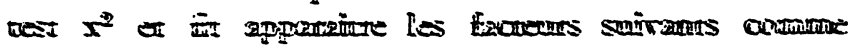

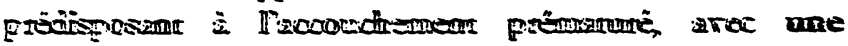

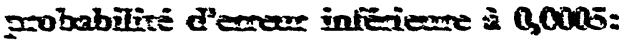

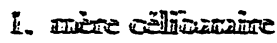

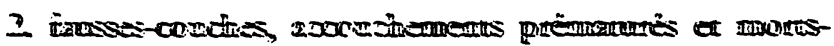
mò zar

5. Tremeandx

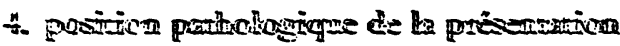

5. Plavorntz pratria

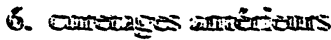

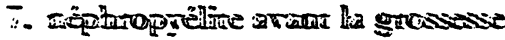

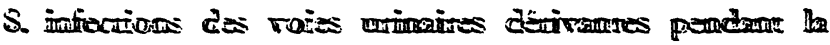
yrasese

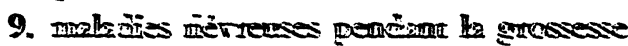

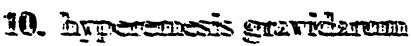

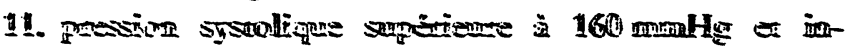

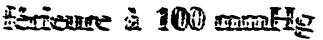

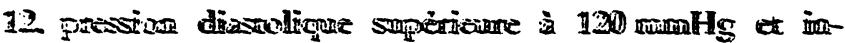

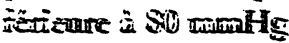

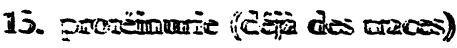

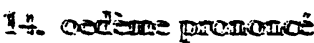

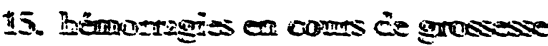

16.

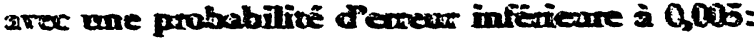

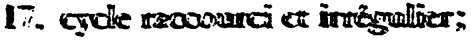

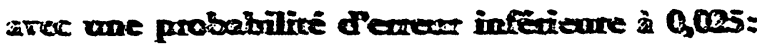

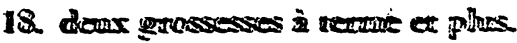

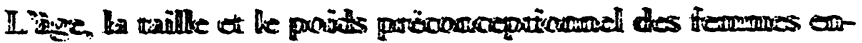

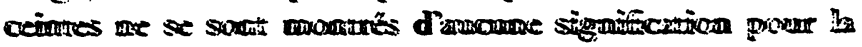

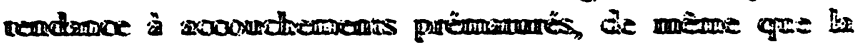

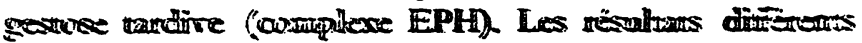

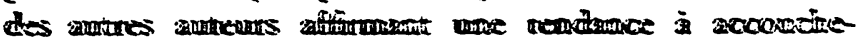

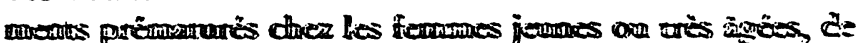

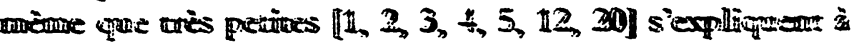

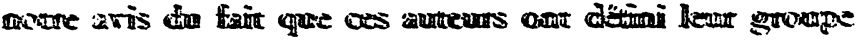

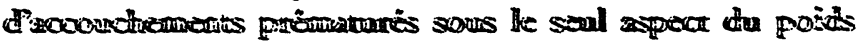

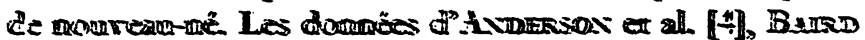

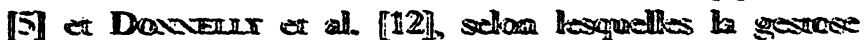

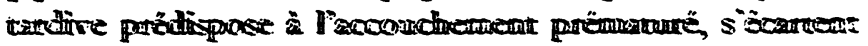

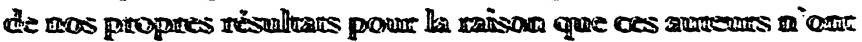

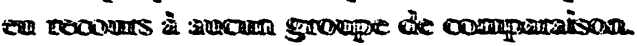

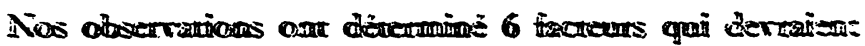

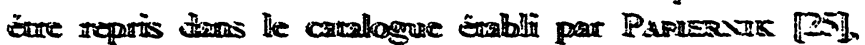

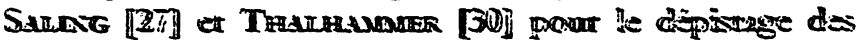
risques d"acoouctherneme prènumur:

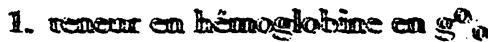

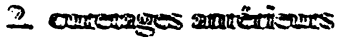

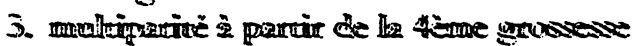

4. cedinge

5. myperronia

6. proveinumie

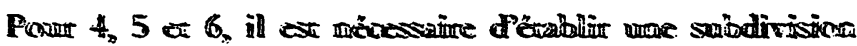

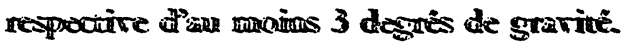

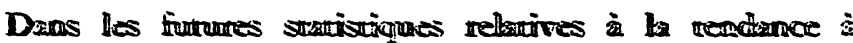

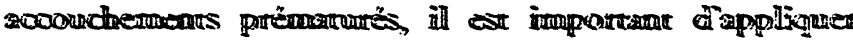

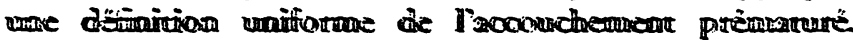

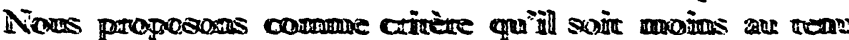

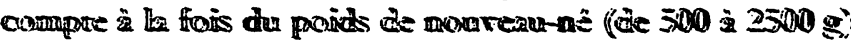

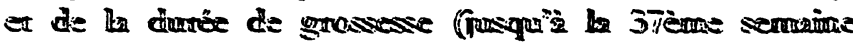
comaprise).

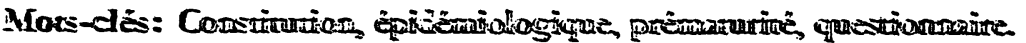

\section{Acisowiedgemex:}

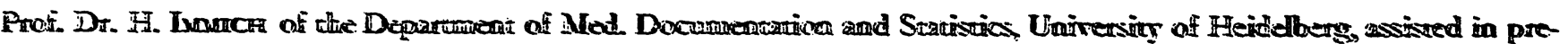

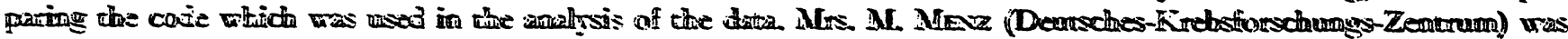

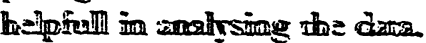

\section{Bibliography}

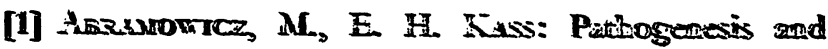
progmanis of premanarize. Niew Erugl. I. Med. 275 (1960) 938

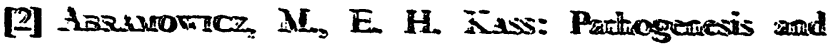

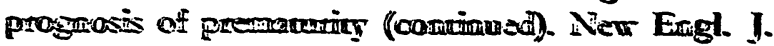
Med. 2715 (1960) 100 :

[3] Hagwowicz, M., E. H. Kuss: Patagramis and pregmosis of premanterity (comlledod). New Engl. I. Mod. $2 \pi j(1960) 1053$

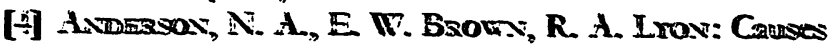
of prementraicy. I. Cormpariscon of meanermal hissorias

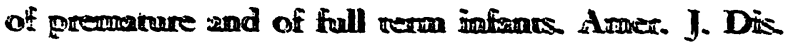
Child 61 (1941) "i?

IS] BuIRD, D.: The epidemiolog of prementmitr. I. Podiuat. 65 (1964) 909

[6. BENEDEX, A. Das Schichsal der Frucht nach drohear der Folngeburt. Z Geburasth. Gymin. 122 (19;1) 106

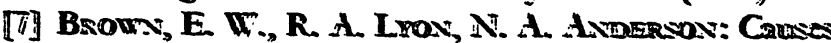
of prementurity. VII. Influence of mterine bleeding on the incidanoe of premeanuricy. Amer. J. Dis Child. "I (1946) 482

[8] Brown, E. W., R. A. Lrov, N. A. Axberson: Causes 
of prematurity. VIII. Influcnce of infections, chronic disorders and accidents on the incidence of prematurity. Amer. J. Dis. Child. 72 (1946) 189

[9] Döring, G. K.: Verkürzte und verlängcrte Tragæcit. In: Kästé, O. et al.: Gynäkologic u. Geburtshilfe, Bd. II. 'Thicme, Stuttgart 1967

[10] Düring, G. K., G. FINK: Uber die Korrelation zwischen Tragzeit und meßbaren Reifemerkmalen bci 11300 Zwillingskindern. Arch. Gynäk. 194 (1960) 63

[11] Donnielly, J. F., J. R. Abernathy, R. N. Creadick, Cil. [̇. Flowles, B. G. Grlenberg, H. B. Wrels: Fetal, parental, and environmental factors associated with perinatal mortality in mothers under 20 years of agc. Amcr. J. Obstet. Gynec. 80 (1960) 663

[12] Donnillly, J. F., Cil. l:. Fiowers, R. N. Creadick, H. B. Wrlls, B. G. Greenterg, K. B. Surles: Maternal, fetal and environmental factors in prematurity. Amcr. J. Obstet. Gyncc. 88 (1964) 918

[13] Drillien, C. M.: The social and cconomic factors affecting the incidence of premature birth. J. Obstet. Gynacc. Brit. Emp. 64 (1957) 161

[14] EffkemanN, G., H. lrmer: Uber dic Ursachen und den Aufzuchtswert der Frühgeburten. Z. Geburtsh. Gynäk. 122 (1941) 368

[15] Fink, A., W. Tilewangle: Dic Frühgeburten an der II. Univ.-Frauenklinik Wien. Z. Geburtsh. Gynäk. 122 (1941) 3183

[16] Frazier, T. M., G. H. Davis, H. Goldstein, I. D. Goldrerg: Cigarettc smoking and prematurity: a prospective study. Amer. J. Obstet. Gynec. 81 (1961) 988

[17] Geigy: Wissenschaftliche Tabellen. 7. Auflage 1968

[18] Higdon, A. L.: Pregnancy in the women over forty. Amer. J. Obstet. Gynec. 80 (1960) 38

[19] Hilfrici, H. J., U. Neeb: Geburtshilfliche Prognose nach Blutungen in der ersten Hälfte der Schwangerschaft. Geburtsh. u. Frauenheilk. 30 (1970) 514

[20] Hoyer, H., O. Thinlhammer: Geburtshilfliche und sozioökonomische Faktoren in der Genese der Frühgeburt (Gewichtsdefinition). Geburtsh. u. Frauenheilk. 28 (1968) 709

[21] KrRChHoff, H.: Der Einfluß endogener Faktoren (Ovarialinsuffizienz) und exogener Faktoren (Berufsarbeit) auf die Entstehung von Frühgeburten. Gcburtsh. u. Frauenheilk. 7 (1948) 78

[22] KLen, L.: Premature birth and maternal prenatal anemia. Amer. J. Obstet. Gynec. 83 (1962) 588

[23] Lav, H.: Frühgeburt (abnorm kurze Tragzcit), Frühreife, Unreife. In: Schwalm, H., G. Döderlein:
Klinik der Frauenheilkunde und Geburtshilfe. Bd. I. Urban-Schwarzenberg, München-Berlin-Wien 1964

[24] MacGrigok, M. W.: Matcrnal ancmia as factor in prematurity and perinatal mortality. Scottisch M. J. 8 (1963) 134

[25] Papiernik-Berkilauek, F..: Coefficicnt de Risque D'accouchement Prématuré (C. R. A. P.). La Pressc Medicalc 77 (1969) 793

[26] Sala, N. L., R. A. Rubi, H. M. Gaidan, H. N. BoGETr: Experimental urinary infection in rats: Pregnancy outenme and its relationship to uterinc contractility. Amcr. J. Obstct. Gyr.ce. 117 (1973) 255

[27] S^lıng, E.: Prämaturitäts- und DysmaturitätsPräventionsprogramm (PDP-Programm). Z. Gcburtsh. u. Perinat. 176 (1972) 70

[28] Simpson, W. J., I. I.NDA: A preliminary report on cigarettc smoking and the incidence of prematurity. Amer. J. Obstet. Gynec. 71 (1957) 808

[29] Thalıiammer, O.: Ursachen der Frühgeburtlichkeit und Möglichkeiten der Prophylaxe. Wien. Med. Wschr. 11/78 (1960) 399

[30] Tihaliammer, O.: Verhütung von Frühgcburtlichkeit und pränataler Dystrophic. I. Ein einfaches System zur Vorausberechnung des FrühgeburtsRisikos sowic des Aufwandes und Nutzens bei Ausschaltung von Risiko-Faktoren. Z. Geburth. u. Perinat. 177 (1973) 169

[31] Terris, M., E. M. Gold: An epidemiologic study of prematurity. I. Relation to smoking, heart volume, employment, and physique. Amer. J. Obstet. Gynec. 103 (1969) 358

[32] Terris, M., F. M. Gol.D: An epidemiologic study of prematurity. II. Relation to prenatal carc, birth interval, residential history, and outcome of previous pregnancies. Amcr J. Obstet. Gynec. 103 (1969). 371

[33] Wallner, H., J. Breitner, M. Scimidt: Analyse von 480 Geburten nach Blutungen in der Schwangerschaft. Münch. med. Wschr. 113 (1971) 690

[34] Wilkerson, L. R., J. F. Donnelly, J. A. Abernathy: Perinatal mortality and premature births among pregnancies complicated by threatened abortion. Amer. J. Obstet. Gynec. 96 (1966) 64

[35] Wilson, M. G., A. H. Parmelee, M. H. Huggins: Prenatal history of infants with births weights of 1, 500 grams or less. Pediat. 63 (1963) 1140

[36] Wolpram, E.: Frühgeburtenaufzucht unter den Nachkriegşyerhältnissen. Zbl. Gynäk. 70 (1948) 1155
Prof. Dr. med. H. Weidinger

Univ. Frauenklinik Mannhcim

Fakultät für Klinischc Mcdizin Mannheim der Universität Heidelberg

Postfach 23

D-68 Mannheim 1/Germany 